\title{
Evaluation of stabilization rate of high and low molecular organic matter in cryoconite holes from the Arctic, Antarctic and Caucasus mountain ecosystems by ${ }^{13} \mathrm{C}-\mathrm{NMR}$ spectroscopy
}

\author{
Vyacheslav Polyakov ${ }^{1 *}$, Evgeny Abakumov ${ }^{1}$, Rustam Tembotov ${ }^{2}$, Bulat \\ Mavludov ${ }^{3}$ \\ ${ }^{1}$ Department of Applied Ecology, Faculty of Biology, St. Petersburg State University, \\ 16th Line of V.O., 29, St. Petersburg, 199178, Russia \\ ${ }^{2}$ Laboratory for Soil and Ecological Researches, Federal state budget scientific \\ establishment Tembotov Institute of ecology of mountain territories Russian Academy of \\ Sciences (IEMT RAS), I. Armand street, 37-a, Nalchik, 360051, Russia \\ ${ }^{3}$ Institute of Geography, Russian Academy of Sciences, Staromonetnyy Pereulok, 29, \\ Moscow, 119017, Russia
}

\begin{abstract}
Cryoconite holes are considered as a place of accumulation of organomineral matter, including black carbon. It is formed as a result of incomplete combustion of carboncontaining fragments of natural and anthropogenic origin. Such material is transported by the wind and participates in the formation of cryoconite on the ice surface. The accumulation of organic matter in cryoconite can significantly affect the climate of our planet. To assess the processes of resistance to biodegradation of organic matter in cryoconite, molecular methods of analysis were used. This work presents the qualitative and quantitative evaluation of composition of humic acids, formed in selected cryoconite holes of various geographical regions. To identify them, the ${ }^{13} \mathrm{C}-\mathrm{NMR}$ spectroscopy method was used, which makes it possible to reveal trends in the accumulation of specific structural fragments and the rate of stabilization of cryoconite organic matter. The analysis of the elemental composition revealed that the most condensed macromolecules of humic acids accumulate in cryoconite holes on Mount Elbrus. In the molecules of humic acids, the accumulation of aliphatic structural fragments up to $71-73 \%$ occurs to a greater extent, while the composition of the aliphatic fragments depended on local precursors of humification. In the Arctic and Antarctic ecosystems, humic acids with relatively homogeneous composition are formed. These ecosystems are characterized by the domination of moss-lichen communities, which are characterized by a predominance of lipids and carbohydrates in the chemical composition. Black carbon is an important part of the planetary carbon cycle. Under the conditions of active deglaciation, cryoconite material can enter the periglacial zone, and under the action of soil microorganisms, it can become an additional source of greenhouse gases in the atmosphere.
\end{abstract}

Key words: black carbon, cryoconite, deglaciation, polar region, ${ }^{13} \mathrm{C}-\mathrm{NMR}$ spectroscopy

DOI: $10.5817 / \mathrm{CPR} 2021-2-15$

Received March 1, 2021, accepted December 31, 2021.

*Corresponding author: V. Polyakov<slavon6985@gmail.com>

Acknowledgements: We would like to express our gratitude to Dmitry Bolshiyanov for his help in the selection and delivery of cryoconite to St. Petersburg, as well as his help in interpreting the data regarding the genesis of cryoconite. This work was supported by Russian Foundation for Basic Reasearch, project No 19-05-50107. 


\section{Introduction}

The stability of various groups of organic compounds from soils, water bodies, and cryoconite has been investigated for a long time (Polyakov and Abakumov 2020a, Chukov et al. 2015, Abakumov et al. 2015, Lodygin et al. 2014, Lodygin and Beznosikov 2010, Dziadowiec et al. 1994, Orlov 1990, Hatcher et al. 1981). Studies have focused on stabilization of organic matter, but addressed also the assessment of the soil regime, the intensity of the soil forming factor, as well as the process of removal of pollutants from ecosystems (Baccolo et al. 2020, Amaro et al. 2015, Celis et al. 2014, Knoblauch et al. 2013). Organic matter contains a large set of various structural fragments that are formed under conditions of mineralization and humification. In the course of these processes, labile (readily hydrolyzable) and stable substances are formed (Polyakov and Abakumov 2020a, Lupachev et al. 2017, Semenov et al. 2009). These substances can be accumulated and formed in soil and water systems, as well as on glacial surfaces (Polyakov et al. 2019a, Szymański 2017, Szymański et al. 2015, Dziadowiec et al. 1994). Nowadays, formation of these compounds and their stabilization are studied in order to identify underlying mechanisms. Under the conditions of cryoconite formation, organic matter of various origins accumulates, such as e.g. soil organic matter, undecomposed plant residues, and black carbon as well (Polyakov et al. 2019a, Szymański 2017, Polyakov and Abakumov 2020b).

Black carbon $(\mathrm{BC})$ is one of the shortlived climatic factors ([1]-Council 2019, [2] -AMAP 2015, Stone 2014). BC is formed as a result of incomplete combustion of fossil fuels and biomass, mainly: emissions from transport engines; emissions from wood and coal combustion; emissions from industrial production (metallurgy and petrochemistry); emissions from oil, gas production and wild-fires (Bond et al. 2013,
Andreae and Gelencsér 2006, Bond and Bergstrom 2006). BC accumulates on snow and ice cover, leads to its heating, which in turn leads to their melting in the accumulation site (Reid et al. 2005). The Arctic region, according to the data of regular meteorological observations carried out since 1990, witnessed an increase in the average winter temperature by $3^{\circ} \mathrm{C}$, and, therefore, is considered extremely sensitive and vulnerable region (Acosta Navarro et al. 2016). In recent decades, the area and volume of Arctic ice have been decreasing (Nordli et al. 2014, Notz and Stroeve 2016). Of the total amount of BC accumulated on the surface of the Arctic, pollution from Europe contributes 68\%, followed by emissions from Asia, which bring 22\% (Flanner et al. 2007). BC damages not only Arctic ice, but also the mountain glaciers in the same ways. The warming effect is more evident in mountainous areas due to the pollution of snow and ice than in Arctic or Antarctic ice areas ([1]-Council 2019, [2]-AMAP 2015).

Elbrus is the largest mountain-glacial massif in Russia (Polyakov et al. 2020c, Zolotarev and Kharkovets 2012). In 2007, the total area of the ice sheet was $120 \mathrm{~km}^{2}$. At present, the reserves of ice and perennial firns accumulated in the second half of the $20^{\text {th }}$ century are melting at an unprecedented rate, and they are almost exhausted over a large area in the $3700-4000 \mathrm{~m}$ zone. The recharge boundary on the glacier has risen by $200 \mathrm{~m}$, and the firn consumption increases. In the area of ablation, lava ridges thaw out. The cumulative mass balance has reached its lowest value in the past 50 years. In addition to dust, various aerosols and trace elements (As, Mn, Zn, $\mathrm{Cu}, \mathrm{Cr}, \mathrm{Ni}, \mathrm{Pb}, \mathrm{Cd}$ and $\mathrm{Hg}$ ), the impact of the accumulation of moraine materials on the glaciers surface was studied (Rototaeva et al. 2019). The surface moraine plays a role in the evolution of the glacier, commensurate with the climatic factor. 
In the context of the unpredicted global climatic changes, special attention is also focused on the Arctic and Antarctic ecosystem. Research in the Arctic shows that at current levels of temperature rise, the Arctic Ocean could be ice-free in summer over the next 30-40 years (Serreze et al. 2007, Wang and Overland, 2009, Tunved et al. 2013). This can have a powerful effect on the sources and sinks of atmospheric aerosols, as well as on the properties and distribution of clouds in the Arctic.

The Antarctic ice sheet is an important indicator of climate change and a driver of sea level rise. The Antarctic ice streams contribute about $10 \%$ of the observed global sea level rise. According to some authors, if the glaciers of Antarctica, with the ice in the Arctic, completely melted, the global sea level will rise by $65 \mathrm{~m}$ (Amaro et al. 2015, Feldmann et al. 2019, Hara et al. 2019, Zwally et al. 2017). The mass of Antarctic ice in the coastal and terrestrial parts does not remain unchanged and substantially depends on climate fluctuations. Many studies have been devoted to the issue of degradation/accumulation of glacier mass, but there is still no conclusive view on local $/ \mathrm{reginal} / \mathrm{global}$ level. It is true for e.g. cryoconite holes formation on the surface of glaciers. They are formed under the influence of local accumulation of material within the continent, although the transfer of particles from the Pacific basin has also been noted (Amaro et al. 2015, Dickens et al. 2019, Groenewerg and Beunk 1992).

Cryoconite holes, in addition to changing albedo and their contribution to the deglaciation process, have a threat from the accumulation of priority toxicants (Akilan et al. 2019, Amaro et al. 2015, Baccolo et al. 2020, Casey et al. 2017). Trace elements, radionuclides, and polyaromatic hydrocarbons are transported here with particles of BC (Polyakov et al. 2020a). Cryoconite holes are small ecosystems with a closed cycle of nutrients and a specific microbiome community (Bond et al. 2013, Christner et al. 2003, Singh et al. 2020). In conditions of active deglaciation, this material can be quickly involved in the modern soil-forming process. This can adversely affect the state of soils in the most vulnerable ecosystems of the Arctic and Antarctic, as well as mountainous regions. In these conditions, soil cryogenesis and mass transfer, contaminated material can persist in the soil for a long time and inhibit the microbiological activity of the soil (Ejarque and Abakumov 2016, Szymański et al. 2015, Zubrzycki et al. 2014, Boike et al. 2013). However, cryoconite material can also serve as a biologically active substance and introduce a significant amount of nutrients into the soils of periglacial environments (Polyakov et al. 2020a, b; Abakumov 2008). Taking into account the fact that in cryoconite are in fact accumulations of black and elemental carbon, the process of humification can also take place, with formation of humic acids (HAs) (Polyakov and Abakumov 2020b, Polyakov et al. 2019a).

Normally, the HAs are heterogeneous systems of high and low molecular compounds formed from the decay of plant and animal remnants in terrestrial and aquatic ecosystems (Polyakov and Abakumov 2020a, Polyakov et al. 2019b, Vasilevich et al. 2019, Vasilevich et al. 2018, Lodygin et al. 2017). BC of biogenic origin (formed mainly during wildfires) (Warneke et al. 2009) accumulates under the conditions of cryoconite formation. In general, the material of cryoconite holes is a biologically active substance in which humification, accumulation and destruction of humic substances under the influence of microorganisms occurs (Polyakov and Abakumov 2020b, Polyakov et al. 2019a). This mechanism is quite different from soil humification, because there is no seasonal input of humification precursors, and the climatic conditions in which the transformation of $\mathrm{BC}$ is very different (Vasilevich et al. 2019, Dziadowiec et al. 1994, Orlov 1990, Hatcher et al. 1981). In addition to information on the molecular com- 
position of HAs, data on the elemental composition of HAs play an important role. The elemental composition of HAs represents the percentage of $\mathrm{C}, \mathrm{H}, \mathrm{N}$, and $\mathrm{O}$ elements in them. The high variability of the elemental composition of HAs among different soils is explained by the varying degree of accumulation of elements in the HAs (Polyakov and Abakumov 2020a, Vasilevich et al. 2019, Lodygin et al. 2017). By the ratio of elements, we can determine the leading processes of humification occurring in the soil. Information on the elemental composition of organic substance contribute to understanding of the general principles of molecular construction and some of their properties(Orlov 1990). Nevertheless, along with humification, the processes of weathering of material also occur, which accumulates mainly from local rocks, and $\mathrm{BC}$ is mainly introduced from other regions (Szymański et al. 2015, Abakumov et al.

\section{Material and Methods}

\section{The study sites}

The study area is confined to the Arctic, Antarctic and Mount Elbrus (Central Caucasus) (Fig. 1).

The Cape Baranov is located in the Severnaya Zemlya Archipelago, samples collected from the Mushketov glacier (Bolshevik Island, Severnaya Zemlya Archipelago, $23 \mathrm{~km}$ south of the "Cape Baranov" Arctic Station). The Mushketov Glacier is a glacial dome with an area of about $89 \mathrm{~km}^{2}$ and an ice thickness of about $160 \mathrm{~m}$. It is located on the surface of the upper denudation leveling (Bolshiyanov et al. 2016). The island is composed of the Upper Proterozoic terrigenous complex (sandstones, siltstones, granodiorites). Average annual air temperature is $-14^{\circ} \mathrm{C}$. The area is characterized by stable winds mainly from the southern direction with an average speed of $10-15 \mathrm{~m} / \mathrm{s}$ (Manousakas et al. 2020). By the personal observation
2013, Bronnikova 2011, Schaefer et al. 2008). Therefore, under conditions of active deglaciation in polar and alpine regions, materials saturated with HAs will enter the soil, which will be involved in the modern process of soil formation and will contribute to the transformation of the most vulnerable ecosystems of our planet.

The aim of this work is an estimation of stabilization of organic matter, which is accumulated and formed in cryoconite holes selected from the Arctic, Antarctic and mountain ecosystem based on qualitative and quantitative composition of HAs. To achieve the aim, the following tasks have been set:

- to investigate the elemental composition of HAs;

- to determine the qualitative and quantitative composition of HAs;

- to evaluate the stabilization of organic matter formed in cryoconite holes.

we suppose that mineral material of cryoconite holes is released from under the glacier, i.e. it was formed a long time ago and, due to the movement of the glacier, is pulled up from the lower part to the surface, where it continues to develop at present time.

The Garabashi glacier is part of the Caucasian Mountains and located on Mt. Elbrus. The glacier begins at an altitude of about $4900 \mathrm{~m}$ and ends at $3330 \mathrm{~m}$; its area in the $1980 \mathrm{~s}$ and $90 \mathrm{~s}$ was $4.47 \mathrm{~km}^{2}$. Since 1982 , the glacier has lost $14 \%$ of its volume and $11.4 \%$ of its area. This zone is subjected to active deglaciation, and cryoconite material is, therefore, involved in modern soil formation with the formation of highly productive systems in the regions of seasonal streams. The average annual temperature is $-12^{\circ} \mathrm{C}$ (Rototaeva et al. 2019). 


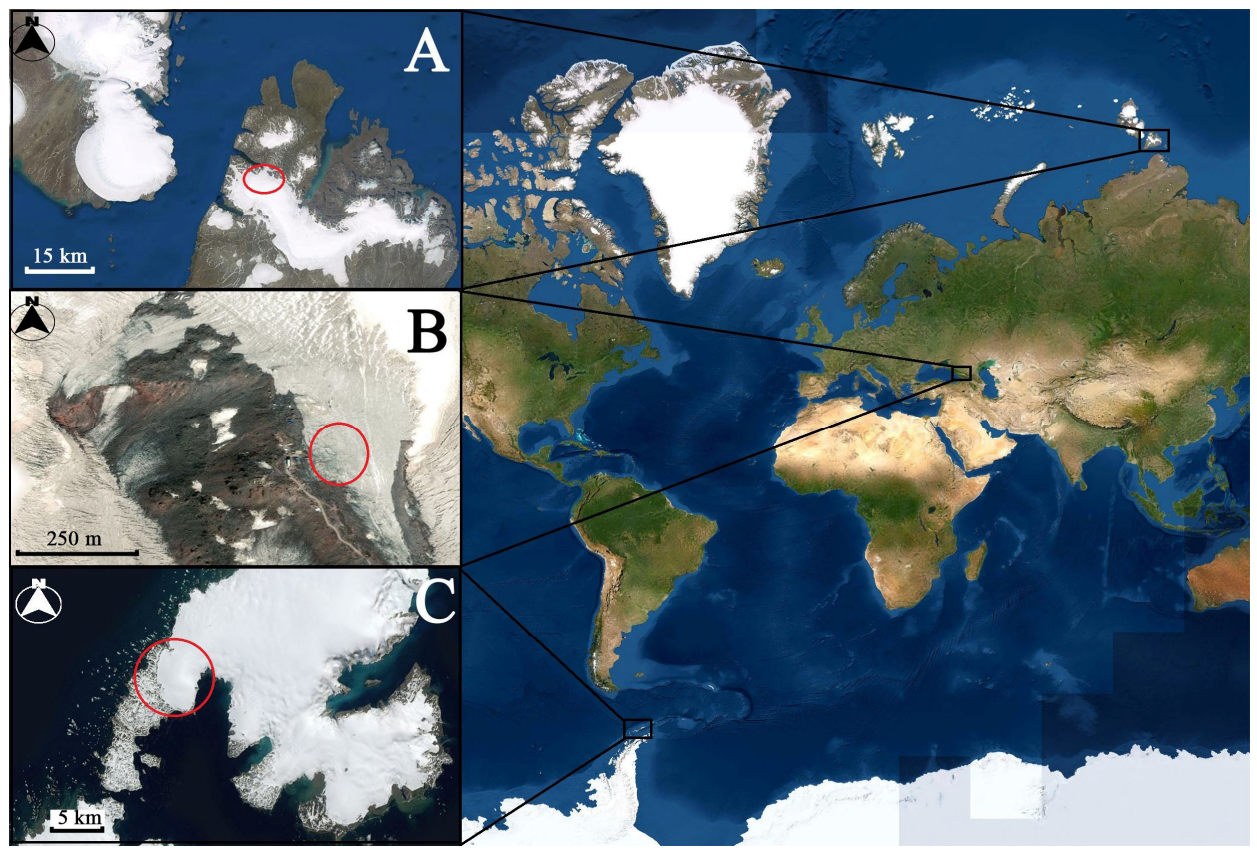

Fig. 1. Study area. A-Mushketov glacier, Cape Baranov, Severnaya Zemlya; B - Elbrus Mountain, Central Caucasus; $\mathbf{C}$ - Collins Ice Cap, Antarctica.

The Collins Ice Cap is located in the West Antarctica region on King George Island, Fildes Peninsula. The maximum height of the ice cap reaches $700 \mathrm{~m}$. The peninsula consists of volcanic rocks, mainly andesites, basalts, and various tuffs. The average annual temperature is $-2.8^{\circ} \mathrm{C}$. A characteristic feature of cryoconite material is its chemical composition corresponding to volcanic sediments (Polyakov et al. 2020a, b). The studied cryoconites are presented in Fig. 2.

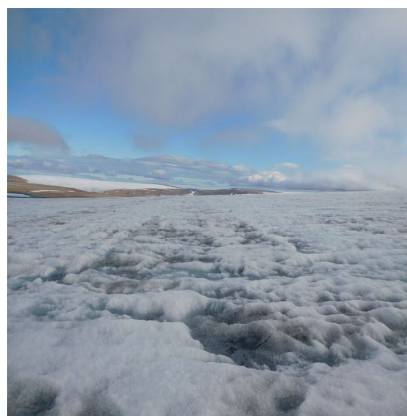

A

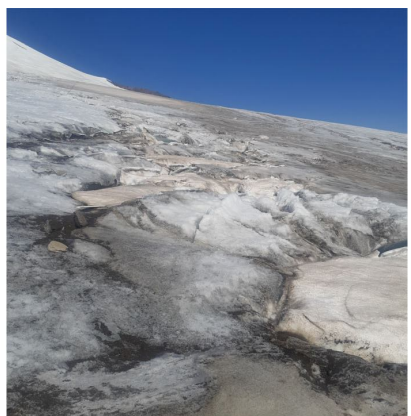

B

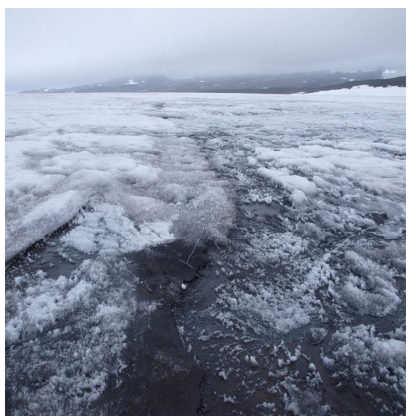

$\mathrm{C}$

Fig. 2. Studied cryoconites. A - Mushketov glacier, Severnaya Zemlya; B - Elbrus Mountain, Central Caucasus; $\mathbf{C}$ - Collins Ice Cap, Antarctica. 


\section{Sampling procedure}

Samples of cryoconite material were taken from the studied glaciers. Samples were taken during the Russian Antarctic and High Latitude expeditions in 2020, from the ice and delivered to the laboratory. A standard $\mathrm{BC}$ isolation method is described by Hegg et al (Hegg et al. 2010). Dried samples were investigated at the De- partment of Applied Ecology of St. Petersburg State University, St. Petersburg. The description of the studied cryoconite is presented in Table 1. Soil from the Elbrus region was sampled according to international standard methods and classified as Calcic Chernozems ([3]-WRB 2015).

\begin{tabular}{|c|c|c|c|c|}
\hline Site & Sample & Coordination & Description & $\begin{array}{c}\text { Initial } \\
\text { material }\end{array}$ \\
\hline \multirow{2}{*}{$\begin{array}{l}\text { Mushketov } \\
\text { glacier, } \\
\text { Cape } \\
\text { Baranov, } \\
\text { Severnaya } \\
\text { Zemlya } \\
\end{array}$} & 1 & $\begin{array}{l}\mathrm{N} 79^{\circ} 05^{\prime} 46.61^{\prime \prime}, \\
\mathrm{E} 101^{\circ} 51^{\prime} 25.35^{\prime},\end{array}$ & $\begin{array}{l}\text { Melting cryoconite from } \\
\text { the glacier }\end{array}$ & \multirow[b]{2}{*}{$\begin{array}{l}\text { Moraine } \\
\text { sediments }\end{array}$} \\
\hline & 2 & $\begin{array}{l}\text { N 7902'56.00”' } \\
\text { E } 101^{\circ} 51^{\prime} 34.52^{\prime \prime}\end{array}$ & $\begin{array}{l}\text { Melting cryoconite from } \\
\text { the glacier }\end{array}$ & \\
\hline $\begin{array}{l}\text { Collins Ice } \\
\text { Cap, } \\
\text { Antarctica }\end{array}$ & 3 & $\begin{array}{l}\text { S 629'21.8”' } \\
\text { W 58 } 54^{\prime} 48.1^{\prime \prime}\end{array}$ & $\begin{array}{l}\text { Cryoconite is formed } \\
\text { during the accumulation } \\
\text { of material from the } \\
\text { atmosphere and bird } \\
\text { activity }\end{array}$ & Volcano \\
\hline \multirow{3}{*}{$\begin{array}{l}\text { Elbrus } \\
\text { Mountain, } \\
\text { Central } \\
\text { Caucasus }\end{array}$} & 4 & $\begin{array}{l}\mathrm{N} 43^{\circ} 33^{\prime} 21.7^{\prime}, \\
\mathrm{E} 43^{\circ} 13^{\prime} 40.1^{\prime}\end{array}$ & $\begin{array}{l}\text { Calcic Chernozems from } \\
\text { the Kiendelen village }\end{array}$ & Soil \\
\hline & 5 & \multirow{2}{*}{$\begin{array}{l}\mathrm{N} 43^{\circ} 18^{\prime} 18^{\prime}, \\
\mathrm{E} 42^{\circ} 27^{\prime} 49^{\prime},\end{array}$} & $\begin{array}{l}\text { The cryoconite from the } \\
\text { ice crack of Garabashi } \\
\text { glacier }\end{array}$ & \multirow[t]{2}{*}{ Volcano } \\
\hline & 6 & & $\begin{array}{c}\text { The cryoconite underlain } \\
\text { by ice }\end{array}$ & \\
\hline
\end{tabular}

Table 1. The description of studied cryoconites.

\section{Cryoconite material analysis, ${ }^{13}$ C NMR spectroscopy and elemental analysis procedure of $\mathrm{HAs}$}

Cryoconite samples were air-dried $\left(20^{\circ} \mathrm{C}\right)$, ground, and passed through $2 \mathrm{~mm}$ sieve. Humic acids were extracted according to a published IHSS protocol (Swift 1996). Solid-state CP/MAS ${ }^{13} \mathrm{C}-\mathrm{NMR}$ spectra of HAs were measured with a Bruker Avance 500 NMR spectrometer in a 3.2-mm $\mathrm{ZrO}_{2}$ rotor. The magic angle spinning (MAS) frequency was $20 \mathrm{kHz}$ in all cases and the nutation frequency for cross polarization (CP) was $\mathrm{u} 1 / 2 \mathrm{p} 1 / 462.5 \mathrm{kHz}$.
Repetition delay was 3 seconds. The number of scans was 6500-32000. Contact time is $0.2 \mu \mathrm{s}$ (Polyakov and Abakumov 2020a).

To conduct a graphical analysis of the elemental composition $(\mathrm{C}, \mathrm{O}, \mathrm{N}, \mathrm{H})$, we used the van Krevelen diagram (van Krevelen 1950), using the $\mathrm{H} / \mathrm{C}-\mathrm{O} / \mathrm{C}$ ratios to identify the direction of the transformation processes of various organic compounds in natural conditions. Under the conditions of 
cryoconite formation, $\mathrm{BC}$ and soil organic carbon accumulates from the atmosphere and has no direct connection with local soil processes in the study region. At the same time, this analysis allowed to evaluate the processes taking place in the studied cryoconite and compare them with soil samples. Elemental compositions were cor-

\section{Results and Discussion}

\section{Elemental composition of studied cryoconite}

The elemental composition of HAs is quite different depending on the geographic location and factors influencing the accumulation of $\mathrm{BC}$. Atomic ratios $(\mathrm{C} / \mathrm{N}$, $\mathrm{H} / \mathrm{C}, \mathrm{O} / \mathrm{C}$ ) are suitable for assessing their composition. The elemental composition and atomic ratios of the studied HAs are presented in Table 2. $\mathrm{C} / \mathrm{N}$ ratio varied from 7.58 to 17.58 and was determined from a high to a very low degree of carbon enrichment with nitrogen. At the same time, the average values of carbon were found rather low relative to natural soils (46-62\%) with a high content of oxygen (45-50\%).

In Table 2, a comparison of the studied cryoconite with HAs from natural soils located in the Arctic, Antarctic and a cryoconite sample is presented and supplemented with data from the Spitsbergen archipelago (Polyakov et al. 2019a). Arctic samples (No. 1-2) showed $\mathrm{C} / \mathrm{N}$ ratio quite close to natural soils, similarly to the cryoconite from the Spitsbergen archipelago. Apparently, this is due to a single principle of material accumulation and homogeneity of this material. In the sample from Antarctica (No. 3), the carbon content is estimated as the lowest due to the fact that local ecosystems in general have a low content of organic content (Gedgafova et al. 2019, Khakunova et al. 2018). The low carbon content in the HAs composition can also be associated with increased acidity and moisture content of the initial samples (Orlov 1990). Under such conditions, the condensation process is difficult and rected for gravimetric water and ash content. Oxygen content was calculated by difference of whole samples mass and gravimetric concentration of $\mathrm{C}, \mathrm{N}, \mathrm{H}$ and ash.

To identify the statistical relationship between the studied compounds, we proposed Spearmen's correlation. the hydrolytic decomposition of humic compounds is enhanced (Vasilevich et al. 2018, Lodygin et al. 2017). Moreover, the elemental composition varied quite strongly in the studied samples, and this is due to the intensity of biological (biochemical) processes occurring in the soils.

A relatively high carbon content was found in the samples from cryoconite holes from Mount Elbrus No. 5-6 (37$39 \%$ ). Actually, here, as well as in the soils formed at the foothills of the mountain (No. 4), the most favorable conditions for the humification of organic compounds are apparent. The foothills of Elbrus are quite productive ecosystems. Here, in the conditions of the formation of Chernozems, a large number of agricultural crops are grown. Dry conditions, plowing of land and erosion processes lead to the transfer of organomineral particles by the aeolian process to the nearest obstacles, which can be mountain ranges.

The van Krevelen diagram for the $\mathrm{H} / \mathrm{C}-\mathrm{O} / \mathrm{C}$ ratios makes it possible to identify the direction of the transformation processes of various organic compounds into natural conditions (Orlov 1990). Under the conditions of studying cryoconite deposits selected from completely different natural conditions, the accuracy of this method increases significantly. Figure 3 shows the resulting diagram of the average molar ratios $\mathrm{H} / \mathrm{Cmod}-\mathrm{O} / \mathrm{C}$ in the studied HAs. 


\begin{tabular}{|c|c|c|c|c|c|c|c|c|c|}
\hline Sample & $\mathbf{C}$ & $\mathbf{H}$ & $\mathbf{N}$ & $\mathbf{O}$ & $\mathbf{C} / \mathbf{N}$ & $\mathbf{H} / \mathbf{C}$ & $\mathbf{O} / \mathbf{C}$ & $\mathbf{H} / \mathbf{C m o d}$ & $\mathbf{w}$ \\
\hline 1 & 14 & 3 & 1 & 82 & 16.33 & 2.55 & 4.40 & 8.44 & 6.24 \\
\hline 2 & 17 & 3 & 2 & 78 & 9.92 & 2.10 & 3.44 & 6.71 & 4.79 \\
\hline 3 & 8 & 2 & 1 & 89 & 9.33 & 2.97 & 8.35 & 14.16 & 13.73 \\
\hline 4 & 52 & 5 & 3 & 38 & 17.58 & 1.31 & 0.56 & 2.06 & -0.19 \\
\hline 5 & 39 & 6 & 6 & 49 & 7.58 & 1.83 & 0.94 & 3.09 & 0.06 \\
\hline 6 & 37 & 5 & 5 & 53 & 8.63 & 1.61 & 1.08 & 3.05 & 0.54 \\
\hline Mean & 28 & 4 & 3 & 65 & 11.56 & 2.06 & 3.13 & 6.25 & 4.19 \\
\hline SD & 17.29 & 1.55 & 2.10 & 20.80 & 4.27 & 0.61 & 2.98 & 4.59 & 5.39 \\
\hline Coeff. var. & 62.12 & 38.73 & 69.92 & 32.07 & 36.91 & 29.80 & 95.43 & 73.42 & 128.43 \\
\hline $\begin{array}{c}\text { Cryoconite } \\
\text { from } \\
\text { Spitsbergen }\end{array}$ & 43 & 6 & 5 & 46 & 10.5 & 1.62 & 0.80 & 2.69 & -0.02 \\
\hline $\begin{array}{c}\text { Soil-like } \\
\text { body from } \\
\text { Lena river } \\
\text { Delta }\end{array}$ & 36 & 5 & 3 & 42 & 16.82 & 1.38 & 0.72 & 2.35 & 0.06 \\
\hline $\begin{array}{c}\text { Soil from } \\
\text { King- } \\
\begin{array}{c}\text { George isl., } \\
\text { Antarctica }\end{array}\end{array}$ & 35 & 5 & 6 & 54 & 6.23 & 1.70 & 1.16 & 3.25 & 0.62 \\
\hline $\begin{array}{c}\text { Cryosol }_{\text {from }} \\
\text { Vaigach isl., } \\
\text { Arctic }\end{array}$ & 48 & 6 & 5 & 36 & 11.29 & 1.42 & 0.55 & 2.2 & -0.3 \\
\hline
\end{tabular}

Table 2. Elemental composition of the studied HAs from cryoconite. Gravimetric concentration is given for $\mathrm{C}, \mathrm{H}, \mathrm{O}$ and $\mathrm{N}$ content. $\mathrm{C} / \mathrm{N}, \mathrm{H} / \mathrm{C}, \mathrm{O} / \mathrm{C}, \mathrm{H} / \mathrm{Cmod}$ and "w" were calculated from mole fraction of $\mathrm{C}, \mathrm{H}, \mathrm{O}$ and $\mathrm{N}$ content. $\mathrm{H} / \mathrm{Cmod}$ is the number of substituted hydrogen atoms in HAs; W indexes were calculated according to (Orlov 1990). Sample numbers correspond to Table 1. Note: ${ }^{1}$ (Polyakov et al. 2019a), ${ }^{2}$ (Polyakov and Abakumov 2020a), ${ }^{3}$ (Polyakov and Abakumov 2020b), ${ }^{4}$ (Polyakov et al. 2019b).

The studied samples are located in three clusters relative to their geographical location and their carbon content (Fig. 3). The lower $\mathrm{H} / \mathrm{Cmod}$ index indicate the higher level of condensation of macromolecules in HAs samples. As expected, the highest level of macromolecule condensation is observed in the Chernozems from Elbrus (No. 4). In addition, local biological (biochemical) processes determine the intensity of condensation of macromolecules in cryoconite holes. Thus, the most condensed macromolecules accumulated on the Mount Elbrus, followed by samples from Mushketov glacier (Cape
Baranov). The lowest level of molecular condensation was found in Antarctic samples. The " $w$ " index used in Table 2 reflects the oxidation state of the HAs. The oxidizing conditions of the environment are generally associated with the ability to migrate elements, in particular iron and aluminum ions, which actively migrate in weakly acidic to acidic solutions (Vasilevich et al. 2018, 2019; Lodygin et al. 2017). Weak reduction conditions are associated with the formation of fresh organic residues and the process of humification (Orlov 1990). All cryoconite samples are in oxidizing conditions, while the weakest 
processes are observed in HAs from Mount Elbrus, which may indicate the transformation of organic matter. A clear process of humification is observed in the soil sample under weakly reduction conditions. This might be also confirmed by the low degree of the $\mathrm{H} / \mathrm{Cmod}$ ratio. Nowadays, it is difficult to identify which processes affect the condensation of macromolecules in cryoconite samples. In our opinion, the leading factor influencing the condensa- tion is the initial origin and composition of BC. Under the conditions of cryoconite formation, a weak transformation of organic matter is observed, and the leading process is mineralization. Based on this, this material can potentially be quickly absorbed by soil microbiota during deglaciation and make a significant contribution to climate change in the planet ([1]-Council 2019, [2]-AMAP 2015).

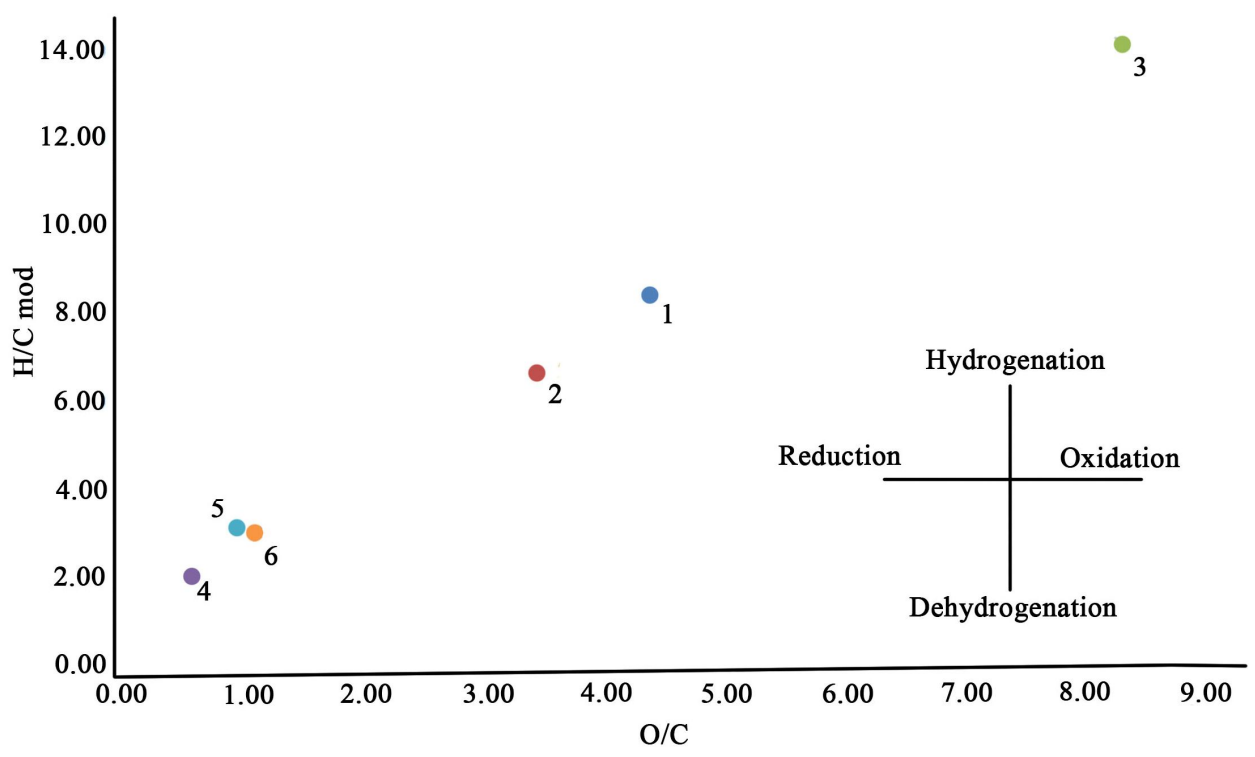

Fig. 3. Elemental composition of the studied HAs isolated from study cryoconite. H/Cmod - the number of substituted hydrogen atoms in the HA. Sample numbers correspond to Table 1.

\section{Characterization of HAs by ${ }^{13} \mathrm{C}-\mathrm{NMR}$ spectroscopy}

Six chemical groups in HAs were identified according to the ${ }^{13} \mathrm{C}-\mathrm{NMR}$ spectroscopy method. C,H-alkyl in 0-46 ppm (C, $\mathrm{H}$-substituted aliphatic fragments), $\mathrm{O}, \mathrm{N}-\mathrm{al}-$ kyl in 46-60 ppm (methoxy and O,N-substituted aliphatic fragments), $\mathrm{OCH} / \mathrm{OCq}$ in 60-110 ppm (aliphatic fragments doubly substituted by heteroatoms (including carbohydrate) and methine carbon of ethers and esters), $\mathrm{C}-\mathrm{C} / \mathrm{C}-\mathrm{H}-\mathrm{AR}$ in 110-160 ppm (C,H-substituted aromatic fragments; $\mathrm{O}, \mathrm{N}$-substituted aromatic frag- ments), $\mathrm{COO} / \mathrm{N}-\mathrm{C}=\mathrm{O}$ in $160-185 \mathrm{ppm}$ (carboxyl groups, esters, amides and their derivatives $), \mathrm{RC}(=\mathrm{O}) \mathrm{R}^{\prime}$ in $185-200 \mathrm{ppm}$ (quinone groups; groups of aldehydes and ketones) (Chukov et al. 2015, Dziadowiec et al. 1994, Hatcher et al. 1981). The chemical shifts are calculated by absolute spectral signals. Samples 1-3 show noises in the signals; this may be due to the relatively high content of clay in the soil samples. Such noises are most typical for soil types such as Chernozems and Fluvisols. 
This is due to the presence of clay in the parent materials, as well as the intake of clay materials by the river. In the studied samples, the wind can transfer the clay and dust particles in the cryoconite holes.

The obtained spectra are presented in Fig. 4. Most of the peaks corresponded to the aliphatic regions $(\mathrm{C}, \mathrm{H}-$ alkyl $\left(\left(\mathrm{CH}_{2}\right) \mathrm{n} / \mathrm{CH} / \mathrm{C}\right.$ and $\left.\mathrm{CH}_{3}\right)$ and $\mathrm{OCH} / \mathrm{OCq}$ groups, as well as the carbonyl group $\mathrm{COO} / \mathrm{NC}=\mathrm{O}$. The aromatic group was cal- culated from the sum of the shifts of 110$185 \mathrm{ppm}$. Aliphatic fragments were calculated from the sum of the shifts of 0 $110 \mathrm{ppm}, 185-200 \mathrm{ppm}$. Chemical shift in $130 \mathrm{ppm}$, which corresponds to aryl carbons of charcoal (Pengerud et al. 2017) and indicates the pyrogenic origin of organic matter, have been detected in cryoconite holes. Data of chemical shifts in the studied soils are presented in Table 3.
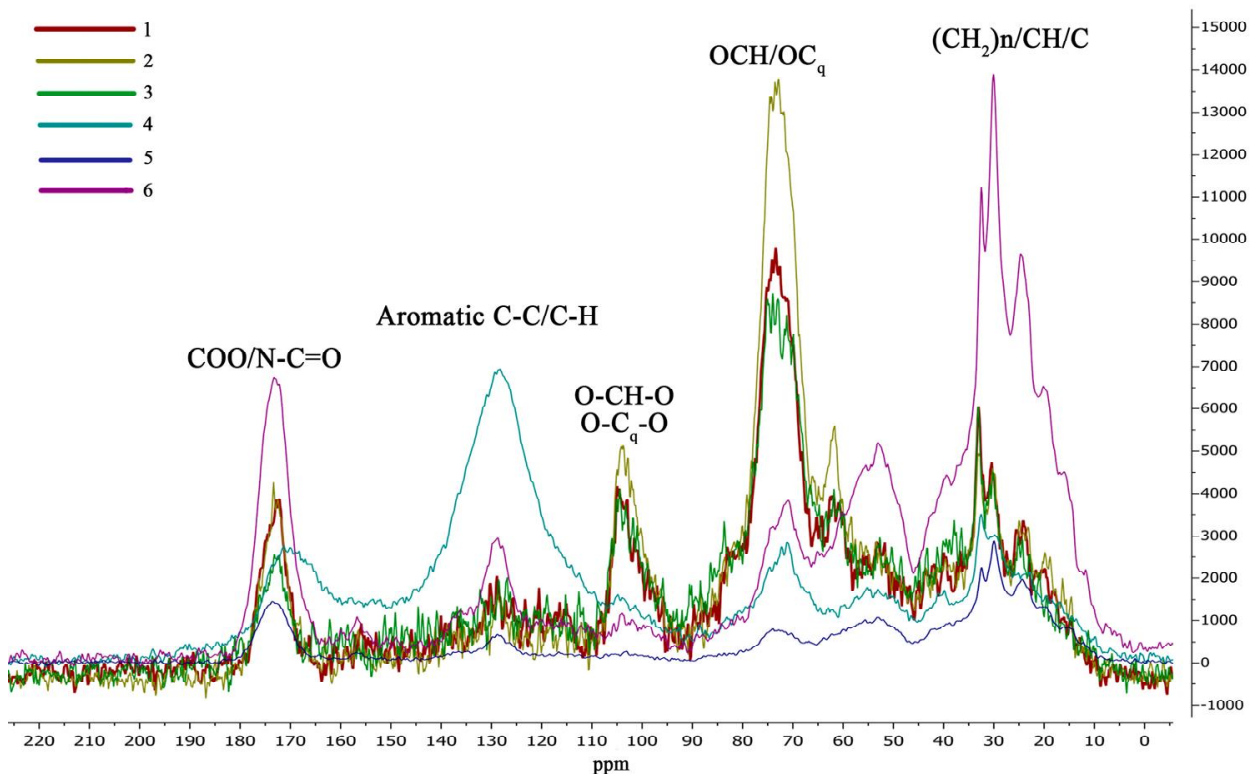

Fig. 4. CP/MAS ${ }^{13} \mathrm{C}-\mathrm{NMR}$ spectra of HAs from studied cryoconites and soil. Numbers correspond to sample numbers (see Table 1). Axis OX - chemical shifts in ppm; Axis OY - Intensity of signal.

Aliphatic fragments of HAs dominate in the studied cryoconite materials and are approximately in the same range of values (71-73\%) (Table 3$)$. This fact indicates that the mechanism of transformation of organic residues in various cryoconite was quite similar. At the same time, the polar regions have practically no differences in the qualitative composition of HAs. Cryoconite's HAs from Elbrus are dominated by $\mathrm{C}, \mathrm{H}-$ and $\mathrm{O}, \mathrm{N}$-alkyl groups; samples from Arctica and Antarctica are dominated by $\mathrm{OCH} / \mathrm{OCq}$ (aliphatic fragments doubly substituted by heteroatoms (including carbohydrate) and methine carbon of ethers and esters) group. Most of the BC is pyrogenic carbon, which is released into the atmosphere during fires (Abakumov et al. 2018, Knicker 2007). During a fire, thermal destruction of HA occurs and the peripheral part of the molecule is separated from the nucleus (Alexis et al. 2010). In HAs molecules, the periphery is represented by aliphatic fragments, which are sepa- 
rated from the aromatic nucleus during a fire and involve in the formation of $\mathrm{BC}$. It is then transported a considerable distance from the fire site and settles on the surface of soil and glaciers (Polyakov et al. 2019a). Therefore, the aliphatic part of HAs in cryoconite carries information about the precursors of humification. In the HAs isolated from polar soils of the Arctic and Antarctica, the content of $\mathrm{OCH} /$ OCq group is significantly higher com- pared to the background of samples from Elbrus. The content of this group may be associated with the precursors of humification (conifers residues) and the content of complex and light ethers in them. In the samples from the Garabashi glacier, the accumulation of $\mathrm{C}, \mathrm{H}$-substituted aliphatic fragments occurs; these fragments are formed mainly from woody and herbaceous vegetation and are quite widespread in the structure of HAs of various soils.

\begin{tabular}{|c|c|c|c|c|c|c|c|c|c|c|c|}
\hline Sample & $\begin{array}{c}\mathrm{C}, \mathrm{H}- \\
\mathrm{AL}\end{array}$ & $\begin{array}{c}\mathrm{O}, \mathrm{N}- \\
\mathrm{AL}\end{array}$ & $\begin{array}{c}\mathrm{OCH} / \\
\mathrm{OC}_{\mathrm{q}}\end{array}$ & $\begin{array}{c}\text { al shift } \\
\mathrm{C}- \\
\mathrm{C} / \mathrm{C}- \\
\mathrm{H}- \\
\mathrm{AR}\end{array}$ & $\begin{array}{l}\% \\
\mathrm{COO} / \\
\mathrm{N}-\mathrm{C}=\mathrm{O}\end{array}$ & $\begin{array}{c}\mathrm{RC}(=\mathrm{O}) \\
\mathrm{R}^{\prime}\end{array}$ & AR & $\mathrm{AL}$ & $\begin{array}{c}\mathrm{AR} / \mathrm{A} \\
\mathrm{L}\end{array}$ & $\begin{array}{c}\text { AL } \\
\text { h,r }+ \\
\text { AR } \\
\text { h,r, } \\
\%\end{array}$ & $\begin{array}{c}\mathrm{C}, \mathrm{H}- \\
\mathrm{AL} / \\
\mathrm{O}, \mathrm{N}- \\
\mathrm{AL}\end{array}$ \\
\hline 1 & 24 & 8 & 37 & 18 & 10 & 3 & 28 & 72 & 0.39 & 42 & 0.53 \\
\hline 2 & 22 & 8 & 40 & 17 & 10 & 3 & 27 & 73 & 0.37 & 39 & 0.46 \\
\hline 3 & 24 & 8 & 38 & 18 & 9 & 3 & 27 & 73 & 0.37 & 42 & 0.52 \\
\hline 4 & 20 & 6 & 21 & 38 & 12 & 3 & 50 & 50 & 1.00 & 58 & 0.74 \\
\hline 5 & 40 & 11 & 19 & 15 & 13 & 2 & 28 & 72 & 0.39 & 55 & 1.33 \\
\hline 6 & 36 & 10 & 20 & 18 & 11 & 5 & 29 & 71 & 0.41 & 54 & 1.20 \\
\hline Mean & 27.67 & 8.50 & 29.16 & 20.67 & 10.83 & 3.17 & 31.5 & 68.5 & 0.48 & 48 & 0.80 \\
\hline SD & 8.23 & 1.76 & 10.11 & 8.57 & 1.47 & 0.98 & 9.1 & 9.1 & 0.25 & 8.21 & 0.37 \\
\hline Coeff. var. & 29.77 & 20.71 & 34.65 & 41.47 & 13.58 & 31.05 & 28.9 & 13.2 & 51.4 & 16.99 & 47.34 \\
\hline $\begin{array}{l}\text { Cryoconite } \\
\text { from } \\
\text { Spitsbergen }\end{array}$ & 34 & 8 & 16 & 31 & 10 & 1 & 41 & 59 & 0.69 & 65 & 1.42 \\
\hline $\begin{array}{l}\text { Soil-like } \\
\text { body from } \\
\text { Lena river } \\
\text { Delta }^{2}\end{array}$ & 22 & 7 & 21 & 33 & 14 & 3 & 47 & 53 & 0.89 & 76 & 0.79 \\
\hline $\begin{array}{c}\text { Soil from } \\
\text { King- } \\
\text { George isl., } \\
\text { Antarctica }^{3}\end{array}$ & 44 & 8 & 18 & 21 & 8 & 1 & 29 & 71 & 0.41 & 65 & 1.69 \\
\hline $\begin{array}{c}\text { Cryosol } \\
\text { from } \\
\text { Vaigach isl., } \\
\text { Arctic }^{4}\end{array}$ & 23 & 8 & 37 & 12 & 18 & 2 & 29 & 71 & 0.42 & 42 & 0.52 \\
\hline
\end{tabular}

Table 3. Percentage of carbon in the main structural fragments of HAs from cryoconites and soil by $\mathrm{CP} / \mathrm{MAS}{ }^{13} \mathrm{C}-\mathrm{NMR}$ spectroscopy. Sample numbers correspond to Table 1; AR - aromatic fraction; $\mathrm{AL}$ - aliphatic fraction; $\mathrm{AL} \mathrm{h}, \mathrm{r}+\mathrm{AR} \mathrm{h}, \mathrm{r} \%$ - hydrophobicity degree; $\mathrm{C}, \mathrm{H}-\mathrm{AL} / \mathrm{O}, \mathrm{N}-\mathrm{AL}-$ the degree of decomposition of organic matter. Note: ${ }^{1}$ (Polyakov et al. 2019a), ${ }^{2}$ (Polyakov and Abakumov 2020a), ${ }^{3}$ (Polyakov and Abakumov 2020b), ${ }^{4}$ (Polyakov et al. 2019b). 
The studied soil from the Kiendelen village accumulated up to $50 \%$ of aromatic fragments. The peaks are located in the regions $\mathrm{C}, \mathrm{H}-$ alkyl $\left(\left(\mathrm{CH}_{2}\right) n / \mathrm{CH} / \mathrm{C}\right.$ and $\left.\mathrm{CH}_{3}\right), \quad \mathrm{OCH} / \mathrm{OCq}, \mathrm{C}-\mathrm{C} / \mathrm{C}-\mathrm{H}-\mathrm{AR}$ and $\mathrm{COO} / \mathrm{N}-\mathrm{C}=\mathrm{O}$ groups. This sample is more condensed; the high content of aromatic fragments is associated with the predominance of herbaceous vegetation, which contains a relatively high content of lignin (Orlov 1990). Lignin is the main building material for aromatic HAs fragments. The pathways of lignin transformation in soils are represented by both the decomposition of monomers and partial changes in the macromolecule. The transformation of lignin leads to a decrease in the group of fragments $-\mathrm{OCH}_{3}$, which is also reflected in the structure of HAs. Demethylation is a characteristic elementary process of humification; the decomposition of lignin leads to the accumulation of the $\mathrm{COOH}$ group. Thus, an increase in the proportion of vascular plants and lignin may indicate the formation of macromolecules that are more resistant to microbial degradation, and indicates the "maturity" of HAs. As a result of the growing season, straw is formed here, which is a fodder base for animals. Plant residues are enriched with nitrogen, carbohydrates, easily and difficultly hydrolyzed polysaccharides and lignin, during the transformation of which high-molecular compounds condense (Polyakov and Abakumov 2020a, Orlov 1990). From the results obtained, it can be seen that the soil sample formed in the Elbrus region is significantly different from the samples from cryoconite that are formed on the Garabashi glacier. This suggests that active processes of humification of organic matter are taking place in the soil, which leads to its stabilization in resistance to biological degradation. It can be seen from the Fig. 4 that peaks in the aromatic region are observed in a similar region, which suggests that aromatic fragments, together with dust, can settle in the Elbrus foothills and form cryoconite. Nevertheless, this is not the main source of organomineral matter in the foothills, since the source of aliphatic compounds is not local soils.

Thus, the studied cryoconite have a very close quantitative composition of structural fragments in the HAs, the AR/AL ratio is $0.37-1$. At the same time, significant differences were noted in the qualitative composition of HAs. Depending on the prosecutors of humification, the quality of plant residues, there are significant differences in the structure of HAs.

\section{Stabilization of organic matter in studied cryoconite and soils}

An important issue is the stabilization of organic matter that accumulates in cryoconite holes. Under the conditions of active deglaciation of the glacier surface, every year more and more material is involved in the current process of soil formation, which leads to significant changes in the landscapes adjacent to the glaciers. This is due to the accumulation of nutrients, risk elements, radionuclides, and the formation of specific microbial communities, under the influence of which a closed cycle of nutrient transformation is formed. A characteristic feature of HAs that are formed in cryoconite holes is their low degree of condensation and accumulation of aliphatic fragments of HAs (up to $73 \%$ ). With the accumulation of such material on the surface of glaciers, their slight transformation occurs due to permanently low temperatures and the absence of seasonal influx of the humification precursors. That organic matter is similar in structure to organic residues that are part of permafrostaffected soils in the Arctic, so we can talk about the deposition of black carbon on the surface of glaciers (Lupachev et al. 2017, Lodygin et al. 2017, Ejarque and 
Abakumov 2016). At the same time, in the context of a climatic crisis, if this organic matter enters the environment, its active mineralization will be observed, which will lead to the emission of carbon dioxide into the atmosphere.

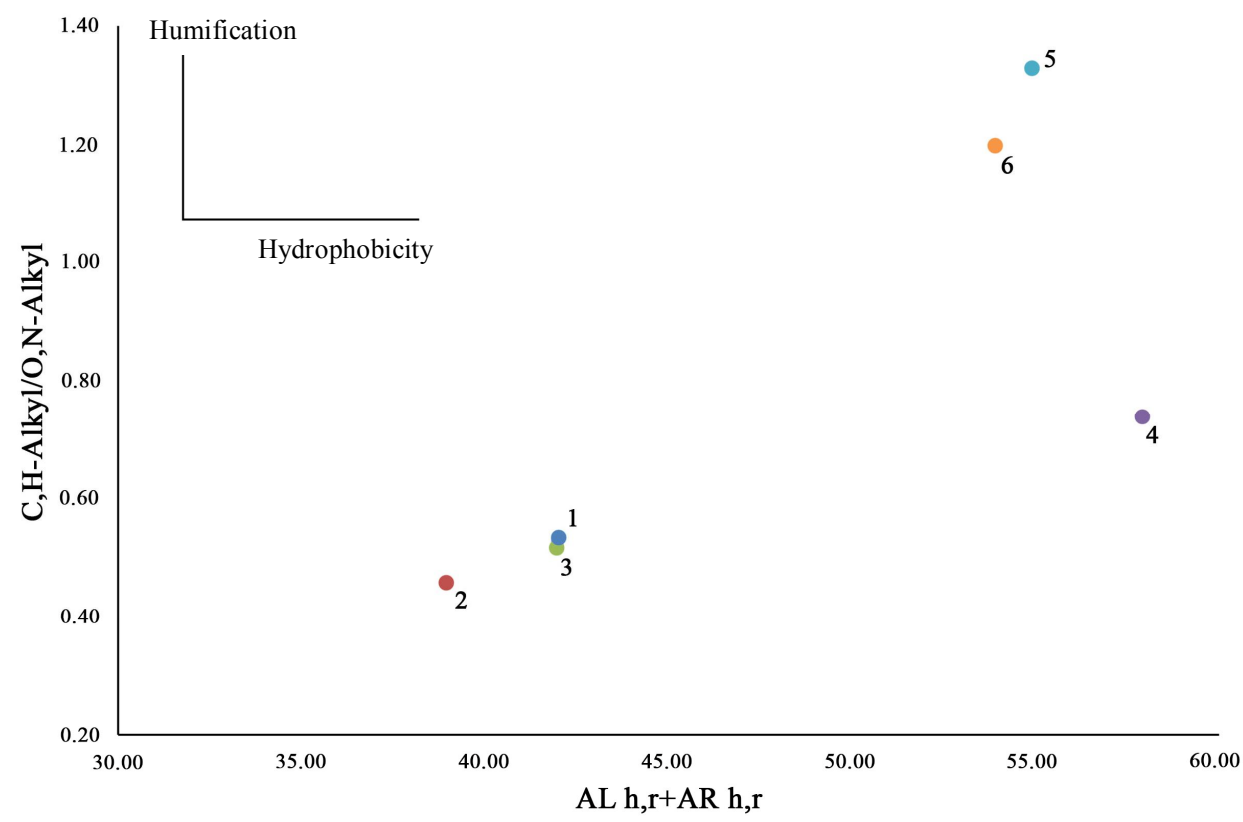

To visualize the process of humification and hydrophobicity of the studied samples, we proposed a diagram of integrated indicators of the molecular composition of HAs (Fig. 5).

Fig 5. The diagram of integrated indicators of the molecular composition of HAs from cryoconite holes and soil. Samples correspond to Table 2; AL h,r + AR h,r indicates the total number of unoxidized carbon atoms.

The highest degree of humification was observed in the cryoconites from Elbrus (Fig. 5). This is due to the qualitative composition of the precursors of humification. The most hydrophobic HAs molecules were found in the soil of the Elbrus region. An increase in the proportion of aromatic fragments of HAs leads to the stabilization of organic matter in the cryoconites of Elbrus. The condensation of macromolecular compounds that include aromatic/unsaturated structures between 110-185 ppm indicates an increase in the degree of hydrophobicity of the soil organic matter and its low availability for the soil microbiome (Vasilevich et al. 2019). Thus, reducing the contribution of greenhouse gases to the climate crisis.

The high correlation was observed in the $\mathrm{RC}(=\mathrm{O}) \mathrm{R}$ 'group with $\mathrm{C}, \mathrm{O}, \mathrm{C} / \mathrm{N}, \mathrm{H} / \mathrm{C}$, $\mathrm{O} / \mathrm{C}, \mathrm{OCH} / \mathrm{OCq}(\mathrm{r}=1)$ and $\mathrm{O}, \mathrm{N}-\mathrm{AL}$ with $\mathrm{C}, \mathrm{O}, \mathrm{H} / \mathrm{C}, \mathrm{O} / \mathrm{C}(\mathrm{r}=1)$, see Fig. 6 . The composition of HAs from cryoconite varied greatly, depending on biological (biochemical) processes, which was reflected in the elemental and qualitative composition of HAs. 


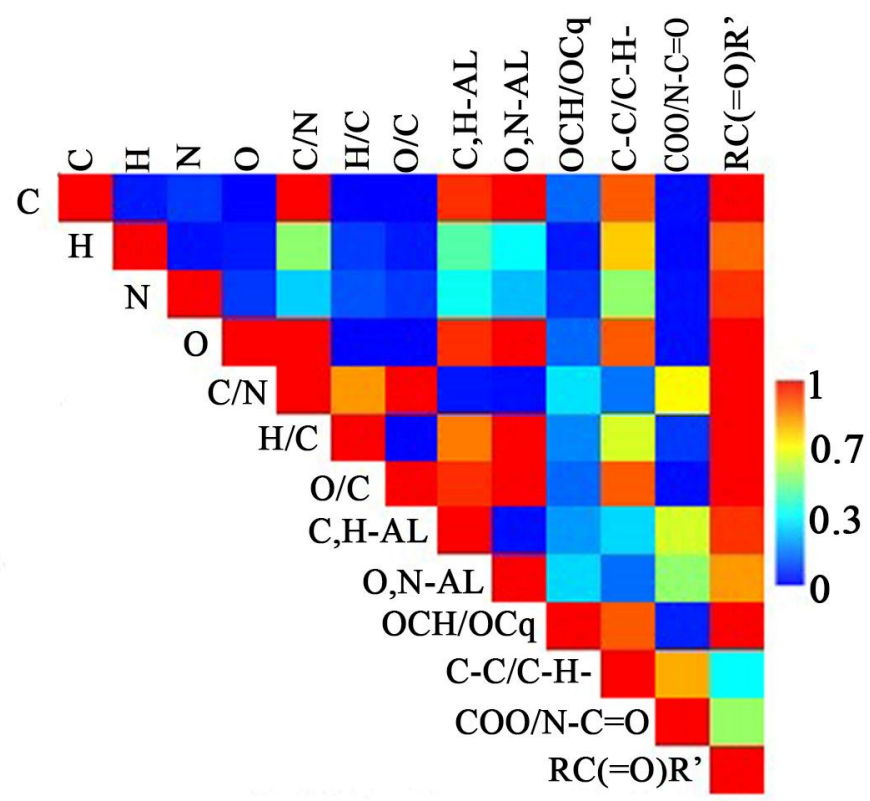

Fig. 6. Spearmen's correlation matrix of HAs fractions.

\section{Conclusions}

Humic compounds formed in cryoconite holes are rather heterogeneous in comparison with natural soils. The elemental composition showed that the most condensed macromolecules accumulated in cryoconites in the area of the Mount Elbrus, while the weak-condensed macromolecules were present in the samples from Antarctica. The composition of HAs of cryoconite is dominated by aliphatic structural fragments $(71-73 \%)$, while the qualitative composition of the aliphatic group is quite different depending on the study area and may be associated with the vegetation cover formed in the immediate vicinity. In conditions of active deglaciation, weakly condensed cryoconite material can be quickly involved in the process of soil formation in the periglacial zone and serve as an additional source of or- ganic carbon. The predominance of aliphatic fragments in the HAs of cryoconite sediments can negatively affect climate change in these regions and on a planetary scale. Aliphatic fragments in HAs are less stable than aromatic fragments. They are more susceptible to hydrolysis and biodegradation, therefore, under conditions of degradation of the ice cover in mountain and polar regions, the organominerals compounds can enter the environment and make an additional contribution to climate change. The studied HAs mainly consist of straight and branched carbon chains, which can be rapidly absorbed during transformation by soil microbiota. With their rapid transformation, a significant amount of carbon dioxide or methane can enter the atmosphere, and have a great impact to the climate crisis. 


\section{References}

Aвакumov, E. (2008): Content of available forms of nitrogen, potassium and phosphorus in ornithogenic and other soils of the Fildes Peninsula (King George Island, Western Antarctica). Biological Communications, 63: 109-116.

ABAKumOV, E., LODYGIN, E. and TomashunAS, V. (2015): ${ }^{13} \mathrm{C}-\mathrm{NMR}$ and ESR characterization of humic substances isolated from soils of two siberian Arctic Islands. International Journal of Ecology. Article ID 390591.7 p.

ABakumov, E., Maksimova, E. and Tsibart, A. (2018): Assessment of postfire soils degradation dynamics: Stability and molecular composition of humic acids with use of spectroscopy methods. Land Degradation \& Development, 29: 2092-2101.

Abakumov, E. V., Gagarina, E. I., SAPEGa, V. F. and Vlasov, D. Y. (2013): Micromorphological features of the fine earth and skeletal fractions of soils of West Antarctica in the areas of Russian Antarctic stations. Eurasian Soil Science, 46: 1219-1229.

Acosta Navarro, J. C., Varma, V., Riipinen, I., Seland, Ø., Kirkevåg, A., Struthers, H., Iversen, T., HANSSON, H. C. and EKMAN, A. M. L. (2016): Amplification of Arctic warming by past air pollution reductions in Europe. Nature Geoscience, 9: 277-281.

Akilan, A., Abdul Azeez, K. K., Schuh, H., Padhy, S. and Kumar Kotluri, S. (2019): Perturbations in atmospheric gaseous components over coastal Antarctica detected in GPS signals and its natural origin to volcanic eruption. Polar Science, 19: 69-76.

Alexis, M. A., Rumpel, C., Knicker, H., Leifeld, J., Rasse, D., Péchot, N., Bardoux, G. and MARIOTTI, A. (2010): Thermal alteration of organic matter during a shrubland fire: A field study. Organic Geochemistry, 41: 690-697.

Amaro, E., Padeiro, A., Mão De Ferro, A., Mota, A. M., Leppe, M., Verkulich, S., Hughes, K. A., Peter, H.-U. and CAnÁrio, J. (2015): Assessing trace element contamination in Fildes Peninsula (King George Island) and Ardley Island, Antarctic. Marine Pollution Bulletin, 97: 523-527.

AndReAe, M. O., Gelencsér, A. (2006): Black carbon or brown carbon? The nature of lightabsorbing carbonaceous aerosols. Atmospheric Chemistry and Physics, 6: 3131-3148.

Baccolo, G., Nastasi, M., Massabò, D., Clason, C., Di Mauro, B., Di Stefano, E., Łokas, E., Prati, P., Previtali, E., Takeuchi, N., Delmonte, B. and Maggi, V. (2020): Artificial and natural radionuclides in cryoconite as tracers of supraglacial dynamics: Insights from the Morteratsch glacier (Swiss Alps). Catena, 191: 104577.

Boike, J., Kattenstroth, B., Abramova, K., Bornemann, N., Chetverova, A., Fedorova, I., Fröb, K., Grigoriev, M., Grüber, M., Kutzbach, L., Langer, M., Minke, M., Muster, S., Piel, K., Pfeiffer, E. M., Stoof, G., Westermann, S., Wischnewski, K., Wille, C. and HubBerTEN, H. W. (2013): Baseline characteristics of climate, permafrost and land cover from a new permafrost observatory in the Lena River Delta, Siberia (1998-2011). Biogeosciences, 10: 2105-2128.

Bolshiyanov, D. Y., Sokolov, V. T., Yozhikov, I. S., Bulatov, R. K., Rachkova, A. N., FEDOROV, G. B. and PARAMZIN, A. S. (2016): Conditions of the alimentation and the variability of glaciers of the Severnaya Zemlya Archipelago from observations of 2014-2015. Ice and Snow, 56: 358-368.

Bond, T. C., Bergstrom, R. W. (2006): Light absorption by carbonaceous particles: An investigative review. Aerosol Science and Technology, 40: 27-67.

Bond, T. C., Doherty, S. J., Fahey, D. W., Forster, P. M., Berntsen, T., Deangelo, B. J., Flanner, M. G., Ghan, S., Kärcher, B., Koch, D., Kinne, S., Kondo, Y., Quinn, P. K., Sarofim, M. C., Schultz, M. G., Schulz, M., Venkataraman, C., Zhang, H., Zhang, S., Bellouin, N., Guttikunda, S. K., Hopke, P. K., Jacobson, M. Z., Kaiser, J. W., Klimont, Z., Lohmann, U., Schwarz, J. P., Shindell, D., Storelvmo, T., Warren, S. G. and Zender, C. S. (2013): Bounding the role of black carbon in the climate system: A scientific assessment. Journal of Geophysical Research: Atmospheres, 118: 5380-5552.

BRonNiKova, M. A. (2011): Interpretation of micromorphological features of soils and regoliths. Eurasian Soil Science, 44: 824-828. 
Casey, K. A., Kaspari, S. D., Skiles, S. M., Kreutz, K. and Handley, M. J. (2017): The spectral and chemical measurement of pollutants on snow near South Pole, Antarctica. Journal of Geophysical Research: Atmospheres, 122: 6592-6610.

Celis, J. E., Barra, R., Espejo, W., GonzÁlez-Acuña, D. and Jara, S. (2014): Trace Element Concentrations in Biotic Matrices of Gentoo Penguins (Pygoscelis Papua) and Coastal Soils from Different Locations of the Antarctic Peninsula. Water, Air, \& Soil Pollution, 226: 2266.

Christner, B. C., Kvitko, B. H. and Reeve, J. N. (2003): Molecular identification of Bacteria and Eukarya inhabiting an Antarctic cryoconite hole. Extremophiles, 7: 177-183.

Chukov, S. N., Abakumov, E. V. and Tomashunas, V. M. (2015): Characterization of humic acids from antarctic soils by nuclear magnetic resonance. Eurasian Soil Science, 48: 12071211.

Dickens, W. A., Kuhn, G., Leng, M. J., Graham, A. G. C., Dowdeswell, J. A., Meredith, M. P., Hillenbrand, C. D., Hodgson, D. A., Roberts, S. J., Sloane, H. and Smith, J. A. (2019): Enhanced glacial discharge from the eastern Antarctic Peninsula since the 1700s associated with a positive Southern Annular Mode. Scientific Reports, 9: 14606.

Dziadowiec, H., Gonet, S. and Plichta, W. 1994. Properties of humic acids of Arctic tundra soils in Spitsbergen. Polish Polar Research, 15: 71.

EJARQUE, E., ABAKUMOV, E. (2016): Stability and biodegradability of organic matter from Arctic soils of Western Siberia: insights from ${ }^{13} \mathrm{C}-\mathrm{NMR}$ spectroscopy and elemental analysis. Solid Earth, 7: 153-165.

Feldmann, J., LeVermann, A. and Mengel, M. (2019): Stabilizing the West Antarctic Ice Sheet by surface mass deposition. Science Advances, 5: 4132.

FlanNer, M. G., Zender, C. S., RANDerson, J. T. and Rasch, P. J. (2007): Present-day climate forcing and response from black carbon in snow. Journal of Geophysical Research: Atmospheres, № 112.

Gedgafova, F. V., Gorobtsova, O. N., Uligova, T. S., Tembotov, R. K. and Khakunova, E. M. (2019): Changes in biological activity of mountain gray forest soils of the Central Caucasus (Terskiy variant of vertical zonation within Kabardino-Balkaria) resultingfrom agricultural use. Eurasian Soil Science, 4: 23-30.

Groenewerg, W. J., BeunK, F. (1992): The petrography and geochemistry of the King George Island Supergroup and the Admiralty Bay Group volcanics, South Shetland Islands. In: J. Lopez-Martinez (ed.): Geologia de la Antartida Occidental, pp. 46-60. Salamanca: III Congreso Geologico de Espanay VIII Congresso Latinoamericano de Geologia.

Hara, K., Sudo, K., Ohnishi, T., Osada, K., Yabuki, M., Shiobara, M. and Yamanouchi, T. (2019): Seasonal features and origins of carbonaceous aerosols at Syowa Station, coastal Antarctica. Atmospheric Chemistry and Physics, 19: 7817-7837.

Hatcher, P. G., Schnitzer, M., Dennis, L. W. and Maciel, G. E. (1981): Aromaticity of humic substances in soils. Soil Science Society of America Journal, 45: 1089-1094.

HegG, D. A., Warren, S. G., Grenfell, T. C., Sarah, J. D. and Clarke, A. D. (2010): Sources of light-absorbing aerosol in arctic snow and their seasonal variation. Atmospheric Chemistry and Physics, 10: 10923-10938.

Khakunova, E. M., Gorobtsova, O. N., Gedgafova, F. V., Uligova, T. S. and Tembotov, R. KH. (2018): Change in biological activity of Central Caucasus mountain Chernozems under agricultural use (within the boundaries of the Elbrus vertical zonation pattern in KabardinoBalkaria). Eurasian Soil Science, 3: 12-18.

KNICKER, H. (2007): How does fire affect the nature and stability of soil organic nitrogen and carbon? A review. Biogeochemistry, 85: 91-118.

Knoblauch, C., Beer, C., Sosnin, A., Wagner, D. and Pfeiffer, E.-M. (2013): Predicting longterm carbon mineralization and trace gas production from thawing permafrost of Northeast Siberia. Global Change Biology, 19: 1160-1172.

Lodygin, E., Beznosikov, V. and Abakumov, E. (2017): Humic substances elemental composition of selected taiga and tundra soils from Russian European North-East. Polish Polar Research, 38: 125-147. 
Lodygin, E. D., BeZnosikov, V. A. (2010): The molecular structure and elemental composition of humic substances from Albeluvisols. Chemistry and Ecology, 26: 87-95.

Lodygin, E. D., Beznosikov, V. A. and Vasilevich, R. S. (2014): Molecular composition of humic substances in tundra soils $\left({ }^{13} \mathrm{C}-\mathrm{NMR}\right.$ spectroscopic study). Eurasian Soil Science, 47 : 400-406.

LUPACHEV, A., ABAKUMOV, E. and GUBIN, S. (2017): The influence of cryogenic mass exchange on the composition and stabilization rate of soil organic matter in cryosols of the Kolyma Lowland (North Yakutia, Russia). Geosciences, 7: 24.

Manousakas, M., Popovicheva, O., Evangeliou, N., Diapouli, E., Sitnikov, N., Shonija, N. and Eleftheriadis, K. (2020): Aerosol carbonaceous, elemental and ionic composition variability and origin at the Siberian High Arctic, Cape Baranova. Tellus B: Chemical and Physical Meteorology, 72: 1-14.

Nordli, Ø., Przybylak, R., Ogilvie, A. E. J. and IsaKsen, K. (2014): Long-term temperature trends and variability on Spitsbergen: the extended Svalbard Airport temperature series, 18982012. Polar Research, 33.

Notz, D., Stroeve, J. (2016): Observed Arctic sea-ice loss directly follows anthropogenic $\mathrm{CO}_{2}$ emission. Science, 345: 747-750.

OrLov, D. S. (1990): Soil humic acids and general theory humification. Moscow, Moscov state University. $327 \mathrm{p}$.

Pengerud, A., Dignac, M.-F., Certini, G., Strand, L. T., Forte, C. and Rasse, D. P. (2017): Soil organic matter molecular composition and state of decomposition in three locations of the European Arctic. Biogeochemistry, 135: 277-292.

Polyakov, V., ABAKumov, E. (2020a): Stabilization of organic material from soils and soil-like bodies in the Lena River Delta $\left({ }^{13} \mathrm{C}-\mathrm{NMR}\right.$ spectroscopy analysis). Spanish Journal of Soil Science, 10: 170-190.

Polyakov, V., Abakumov, E. and Mavlyudov, B. (2020b): Black carbon as a source of trace elements and nutrients in Ice Sheet of King George Island, Antarctica. Geosciences, 10.

Polyakov, V., ABAKUmov, E. V. (2020b): Humic acids isolated from selected soils from the Russian Arctic and Antarctic: Characterization by Two-Dimensional 1H-13C HETCOR and 13C CP/Mas NMR Spectroscopy. Geosciences, 10.

Polyakov, V., Zazovskaya, E. and ABakumov, E. (2019a): Molecular composition of humic substances isolated from selected soils and cryconite of the Grønfjorden area, Spitsbergen. Polish Polar Research, 40: 105.

Polyakov, V. I., AвAKumov, E. V. and Tемвотоv, R. (2020c): Black carbon as a factor in deglaciation in polar and mountain ecosystems: A Review. Vestnik Tomskogo gosudarstvennogo universiteta. Biologiya, 52: 6-33.

Polyakov, V. I., Chegodaeva, N. A. and Abakumov, E. V. (2019b): Molecular and elemental composition of humic acids isolated from selected soils of the Russian Arctic. Vestnik Tomskogo gosudarstvennogo universiteta. Biologiya, 47: 6-21.

Reid, J. S., Koppmann, R., EcK, T. F. and Eleuterio, D. P. (2005): A review of biomass burning emissions part II: intensive physical properties of biomass burning particles. Atmospheric Chemistry and Physics, 5: 799-825.

Rototaeva, O. V., Nosenko, G. A., Kerimov, A. M., Kutuzov, S. S., Lavrentiev, I. I., Nikitin, S. A., Kerimov, A. A. and Tarasova, L. N. (2019): Changes of the mass balance of the Garabashy Glacier, Mount Elbrus, at the turn of $20^{\text {th }}$ and $21^{\text {st }}$ centuries. Ice and Snow, 59.

Schaefer, C. E. G. R., Simas, F. N. B., Gilkes, R. J., Mathison, C., Da Costa, L. M. and AlbuQuerque, M. A. (2008): Micromorphology and microchemistry of selected Cryosols from maritime Antarctica. Geoderma, 144: 104-115.

Semenov, V. M., Ivannikov, L. A. and Tulina, A. S. (2009): Stabilization of organic matter in the soil. Agrochimia, 10: 77-96.

Serreze, M. C., Holland, M. M. and Stroeve, J. (2007): Perspectives on the Arctic's Shrinking Sea-Ice Cover. Science, 315: 1533. 
Singh, P., Tsuji, M., Singh, S. M. and TAKeuchi, N. (2020): Contrasting patterns of microbial communities in glacier cryoconite of Nepali Himalaya and Greenland, Arctic. Sustainability, 12: 6477.

Stone, R. S., Sharma, S., Herber, A., Eleftheriadis, K. and Nelson, D. W. (2014): A characterization of Arctic aerosols on the basis of aerosol optical depth and black carbon measurements. ELEMENTA - Science of the Antropocene, 000027.

SwIFT, R. S. (1996): Organic matter characterization. Methods of Soil Analysis, 1011-1069.

SZYMAŃSKI, W. (2017): Chemistry and spectroscopic properties of surface horizons of Arctic soils under different types of tundra vegetation - A case study from the Fuglebergsletta coastal plain (SW Spitsbergen). CATENA, 156: 325-337.

Szymański, W., Skiba, M., Wojtuń, B. and Drewnik, M. (2015): Soil properties, micromorphology, and mineralogy of Cryosols from sorted and unsorted patterned grounds in the Hornsund area, SW Spitsbergen. Geoderma, 253-254: 1-11.

Tunved, P., StröM, J. and Krejci, R. (2013): Arctic aerosol life cycle: Linking aerosol size distributions observed between 2000 and 2010 with air mass transport and precipitation at Zeppelin station, Ny-Ålesund, Svalbard. Atmospheric Chemistry and Physics, 13: 3643-3660.

van Krevelen, D. W. (1950): Studies of gas absorption. VI. A graphical representation for the efficiency of physical absorption. Recueil des Travaux Chimiques des Pays-Bas, 69: 503-508.

Vasilevich, R., Lodygin, E., Beznosikov, V. and Abakumov, E. (2018): Molecular composition of raw peat and humic substances from permafrost peat soils of European Northeast Russia as climate change markers. Science of The Total Environment, 615: 1229-1238.

Vasilevich, R. S., Beznosikov, V. A. and Lodygin, E. D. (2019): Molecular structure of humus substances in permafrost peat mounds in forest-tundra. Eurasian Soil Science, 52: 283-295.

WANG, M., OverLAND, J. E. (2009): A sea ice free summer Arctic within 30 years? Geophysical Research Letters, 36.

Warneke, C., Bahreini, R., Brioude, J., Brock, C. A., De Gouw, J. A., Fahey, D. W., Froyd, K. D., Holloway, J. S., Middlebrook, A., Miller, L., Montzka, S., Murphy, D. M., Peischl, J., Ryerson, T. B., Schwarz, J. P., Spackman, J. R. and Veres, P. (2009): Biomass burning in Siberia and Kazakhstan as an important source for haze over the Alaskan Arctic in April 2008. Geophysical Research Letters, 36.

Zolotarev, E. A., Kharkovets, E. G. (2012): Development of glaciers of Mount Elbrus after the little ice age. Ice and Snow, 52: 15-22.

Zubrzycki, S., Kutzbach, L. and Pfeiffer, E. M. (2014): Permafrost-affected soils and their carbon pools with a focus on the Russian Arctic. Solid Earth, 5: 595-609.

Zwally, H. J., Li, J., Robbins, J. W., Saba, J. L., Yi, D. and Brenner, A. C. (2017): Mass gains of the Antarctic ice sheet exceed losses. Journal of Glaciology, 61: 1019-1036.

\section{Web sources / Other sources}

[1] Council, A. (2019): Expert Group on Black Carbon and Methane - Summary of Progress and Recommendations 2019.

[2] AMAP 2015. AMAP Assessment (2015): Black carbon and ozone as Arctic climate forcers. Arctic Monitoring and Assessment Programme (AMAP). Oslo, Norway.

[3] WRB, F. 2015. IUSS Working Group WRB World Reference Base for Soil Resources 2014, update 2015. 